\title{
Industrial water demand for agro- processing and beverage industries in Rwanda
}

\author{
Egide Munderere, Omar Munyaneza ${ }^{*}$ (D) and Umaru Garba Wali
}

\author{
* Correspondence: \\ omarmunyaneza1@gmail.com \\ Department of Civil, Environmental \\ and Geomatic Engineering, \\ University of Rwanda, College of \\ Science and Technology, P.O. Box \\ 3900, Kigali, Rwanda
}

\begin{abstract}
Background: Water play important role in industrial operation of food processing, such ingredient of the product, operation of equipment such as boilers, cooling towers, cleaning purposes to ensure a sufficient level of hygiene and food safety etc. Rwanda is rapidly developing and this development is associated with increase in population, urbanization, industrialization, modification of agricultural practices including rise in area of irrigated land etc. All these could cause increase in water uses and modification of water demand. Assessing future water demand of the country requires the understanding of specific water demand of different sectors mentioned above and its variation within those sectors. Growth of industrial sector is expected to rise in Rwanda especially because of the created enabling environment; this of cause will cause the rise in industrial water demand. In order to understand industrial water demand and be able to project it for the future it is necessary to know specific water demand of different type of industries in the country. However, there is no published evidence of this information country wide. It is therefore necessary to conduct industrial water demand assessment in the country. The main of this study is to quantify industrial water demand for different types of industries in Rwanda.
\end{abstract}

Methods: The data used for this study were obtained from records of various food processing industries and breweries, interviews and from relevant organizations such as Rwanda Development Board (RDB), Water and Sanitation Corporation (WASAC), Ministry of Trade (MINICOM), and National Institute of Statistics of Rwanda (NISR). Specific water demand for various products was estimated taking into consideration the amount of water used and quantity of product produced. Correlation method in MATHLAB was used to determine the relationship between water used and production.

Results and discussion: The results show that industrial water used for some industrial production in Rwanda is within the recommend limit example maize flour $2 \mathrm{~m}^{3} /$ ton and breweries such as beer production industry 4 to $4.5 \mathrm{~m}^{3} / \mathrm{m}^{3}$ and carbonate soft drink industries $4 \mathrm{~m}^{3} / \mathrm{m}^{3}$, as against internationally recommended water of $2 \mathrm{~m}^{3} /$ ton, and 6.5 $\mathrm{m}^{3} / \mathrm{m}^{3}$ respectively.

However water uses for of the following, Sugar making industry $29 / \mathrm{m}^{3} / \mathrm{t}$, Meat processing industry $5 / \mathrm{m}^{3} / \mathrm{t}$ and Tomato paste production industry $6 \mathrm{~m}^{3} /$ ton exceeded the internationally recommended which are $25 / \mathrm{m}^{3} / \mathrm{t}, 2 / \mathrm{m}^{3} / \mathrm{t}, 3.58 \mathrm{~m}^{3} /$ ton. Tomato Paste production industry shown strong relationship because as water demand is increasing also production is increasing. Thus from this linear model, about $98 \%$ of the (Continued on next page) 
(Continued from previous page)

variation in water demand can be explained by variation of tomato paste production

due to high relationship between water demand and tomato paste production.

Conclusions: The quantity of water consumption differs between types of industries. It was revealed that the brewing industries uses more water than any other kind of industries in Rwanda this could related the amount of production and demand for the product. There is wide difference in specific water consumption between various industries. Brewery industries in Rwanda have shown best practice of water demand with specific water demand of 4 to $4.5 \mathrm{~m}^{3} / \mathrm{m}^{3}$ of final product in which is less than the global bench mark of $6.5 \mathrm{~m}^{3} / \mathrm{m}^{3}$. Improvements need to be made in order to achieve the recommended best practice of three cubic meters of raw water for every cubic meter of carbonate soft drinks and four cubic meters of raw water for every cubic meter of beer produced.

Keywords: Agro-processing, Beverage industries, Linear model, Water demand, Kigali

\section{Background}

Water is a crucial component in food processing operations and is used in many applications, for instance, as a product ingredient; for operating essential items of equipment such as boilers and cooling towers; and for cleaning purposes to ensure a sufficient level of hygiene and food safety. Rwanda is endowed with abundant water resources although its distribution and availability for use vary widely while some areas of the country face water shortage. Often, industrial waste is being discharged into rivers without treatment. The consequence is that the load of waste exceeds the ability of water bodies to assimilate it resulting in lack of access to clean water and widespread waterborne and water-based diseases.

Rwanda is rapidly developing and this development is associated with increase in population, urbanization, industrialization, modification of agricultural practices including rise in area of irrigated land etc. All these could cause increase in water uses and modification of water demand. Assessing future water demand of the country requires the understanding of specific water demand of different sectors mentioned above and its variation within those sectors. Growth of industrial sector is expected to rise in Rwanda especially because of the created enabling environment; this of cause will cause the rise in industrial water demand. In order to understand industrial water demand and be able to project it for the future it is necessary to know specific water demand of different type of industries in the country. However, there is no published evidence of this information country wide. It is therefore necessary to conduct industrial water demand assessment in the country.

In Rwanda industrial activities that have implications for water demand include agroprocessing (sugar Production, Tomato paste, etc), textile production, tea processing, bottled water production, leather tanning and clay products manufacturing; mining processing; construction industries; beverage industries and chemical and plastic industries, hydropower energy generation etc. About 90\% of manufacturing industries in Rwanda are located in Kigali and Gisenyi, hence most industrial water demand is in the two cities. They are mostly primary industries for agro processing. It is therefore necessary to conduct industrial water demand assessment countrywide particularly in the city of Kigali. 


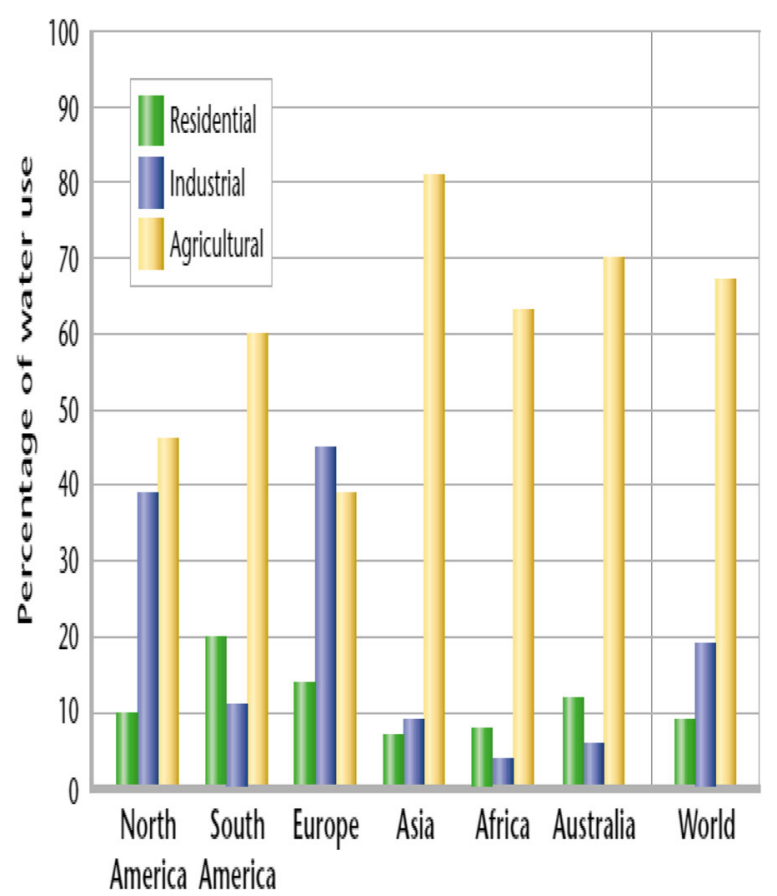

Fig. 1 Water withdrawals by sector by region in 2005

\section{Global water use}

Most of the fresh water used worldwide is used to irrigate crops. Patterns of water use are not the same everywhere, however, the availability of fresh water, population sizes, and economic conditions affect how people use water. In Asia, agriculture accounts for more than $80 \%$ of water use, whereas it accounts for only $38 \%$ of water use in Europe. Industry accounts for about $20 \%$ of the water used in the world as shown in Fig. 1 . The highest percentage of industrial water use occurs in Europe and North America. Globally, about $8 \%$ of water is used by households for activities such as drinking and washing (FAO Aquastat, 2005).

\section{Agro-industrial water demand}

Water is a crucial component in food processing operations and is used in many applications, for instance, as a product ingredient; for operating essential items of equipment such as boilers and cooling towers; and for cleaning purposes to ensure a sufficient level of hygiene and food safety. Table 1 indicates water demand for different types of food processors, a dairy, a meat processing plant and a food ingredients factory.

Table 1 Specific water demand for agro-processing industries (Bob \& Penny, 2004)

\begin{tabular}{ll}
\hline Sector & Consumption \\
\hline Dairy & $1-3 \mathrm{~L} / \mathrm{L}$ raw milk processed \\
Meat & $9.13 \mathrm{~L} / \mathrm{kg}$ product \\
Bakery product & $0.97 \mathrm{~L} / \mathrm{kg}$ product \\
Fruit and vegetables & $8.20 \mathrm{~L} / \mathrm{kg}$ product \\
Oils and fats & $2.05 \mathrm{~L} / \mathrm{kg}$ product \\
\hline
\end{tabular}




\section{Abattoir water demand}

Water is used for the watering and washing of livestock, the washing of trucks, washing of carcasses and by-products, and for cleaning and sterilizing equipment and process areas. Rates of water consumption can vary considerably depending on the scale of the plant, the age and type of processing, the level of automation, and cleaning practices. Typical figures for fresh water consumption are $2-15 \mathrm{~m}^{3}$ per ton of live carcass weight as shown in Table 2.

\section{Study area}

This study was conducted in the City of Kigali, Capital of Rwanda, which is almost located at the centre of the country in the natural area of Bwanacyambwe, close to the Basin of Nyabugogo River. Geographically the centre of Kigali is at $1^{\circ} 57^{\prime}$ Southern latitude and at $30^{\circ}$ 04'of Eastern longitude. Altitude varies from 1500 to $1560 \mathrm{~m}$ according to the place. Approximately $30 \%$ of the surface of the city is consisted of the hills with slopes higher than $20 \%$. The site of the City of Kigali is naturally well protected; it is surrounded by significant mountains: the mount Jali $(2071 \mathrm{~m})$ in the North-West, the mount of Kigali $(1856 \mathrm{~m})$ in the west and the mount Nyarutarama $(1809 \mathrm{~m})$ in the south. The current surface of its entire province is of $730 \mathrm{~km}^{2}$. Currently, it is administratively consisted of three districts which are: the District of Gasabo in north, the District of Kicukiro in south-east and the District of Nyarugenge in south-west as indicated in Fig. 2.

\section{Rwanda industrial policy and master plan 2010-2020}

The plan identifies 4 industrial park locations and 7 future priority zones. In addition the plan foresees between 30 and 40 locations for agro-processing. It also identifies potential clusters in building materials, ICT, leather and leather products, textiles, 13 pharmaceuticals, bio-plastics, minerals processing, dairy products, agro-processing, and tourism \& culture as indicated Fig. 3.

\section{Kigali special economic}

Kigali special economic zone (the former name was Kigali free trade zone) is located in Kigali city, Gasabo district, sector of Ndera in Masoro cell. It was created with main objective of being a central distribution point that can serve the smaller local markets in the region (Rwanda, Burundi, eastern RDC, and Uganda). The national industrial development policy emphasizes on sustainable industrialization, and under the current investment strategy, GoR plans to establish a free economic zone now special economic zone regime including a

Table 2 Specific water demand for abattoir per unit of production (World Bank, 2007)

\begin{tabular}{ll}
\hline Country & $\mathrm{m}^{3} / \mathrm{t} \mathrm{LCW}$ (live cow weight) \\
\hline US & $4.2-16.7$ \\
UK & $5-15$ \\
Europe & $5-10$ \\
Hungary & $2-3.8$ \\
Germany & $0.8-6.2$ \\
\hline
\end{tabular}




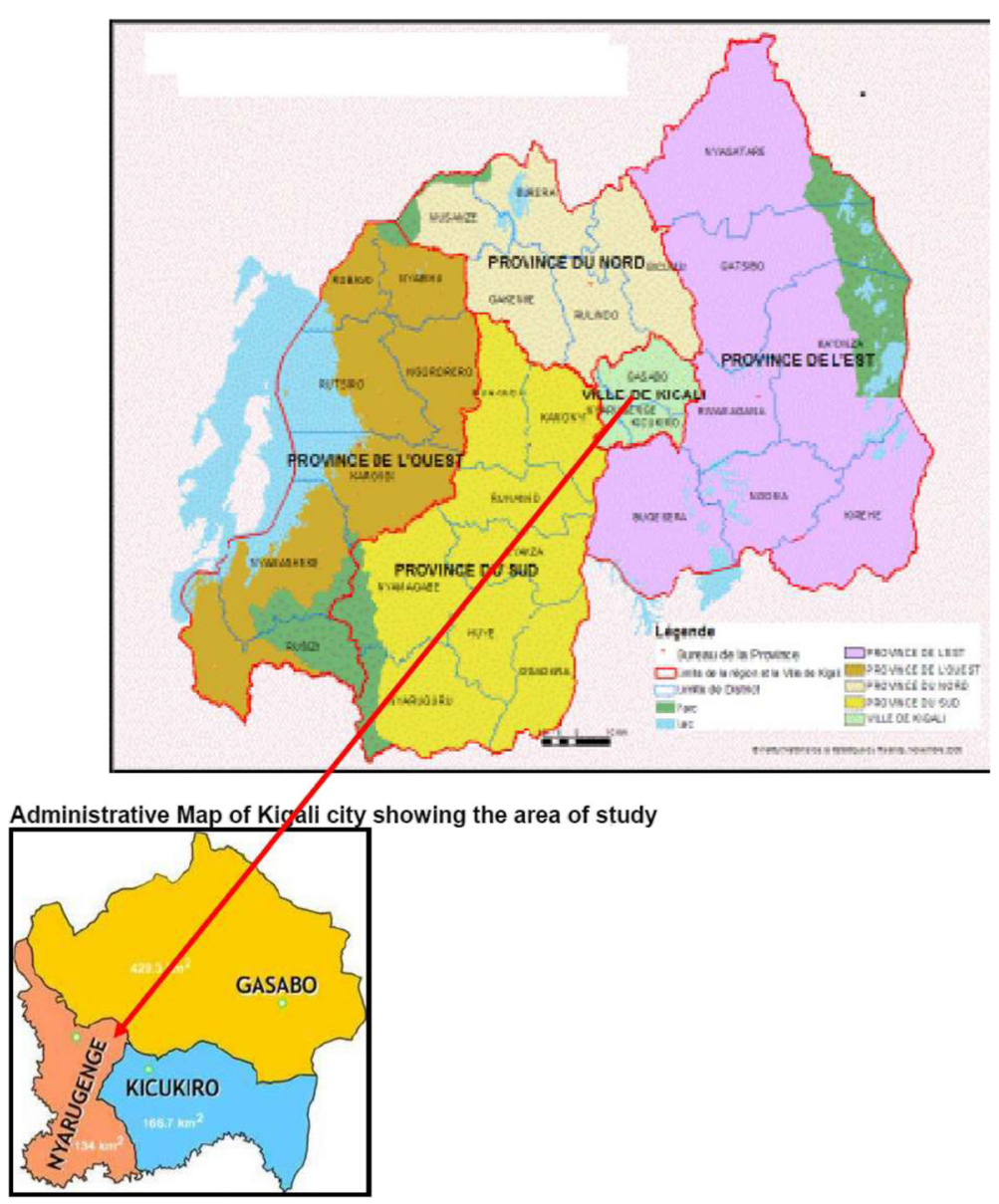

Fig. 2 Administrative Map of Rwanda showing the study area

designated industrial zone with utilities and other support amenities (Fig. 4). If these are realized, they will provide sufficient incentives for sustainable industrial growth in Rwanda.

\section{Methods}

Data for this study was collected from both primary and secondary sources. The primary source of data collection was use of detailed questionnaires concerning water demand and conservation as shown in Table 3. The goal of questionnaires was to collect the most general information about each factory.

The direct interviews were carried out inside each industry, and the interview includes technicians; production officers and others who are responsible for various sections as shown in Table 4. The following institutions were visited and interviewed to get general picture about industrial production; development and water demand in the city of Kigali and in Rwanda generally. Those are: Rwanda Development Board (RDB), Water and Sanitation Corporation (WASAC), Ministry of Trade (MINICOM), and National Institute of Statistics of Rwanda (NISR).

An assessment was conducted for manufacturing industries of food products; beverages; textiles; chemical products; plastics products; metallic products; mining processing industries and others as shown in Table 5. Information was gathered to obtain 


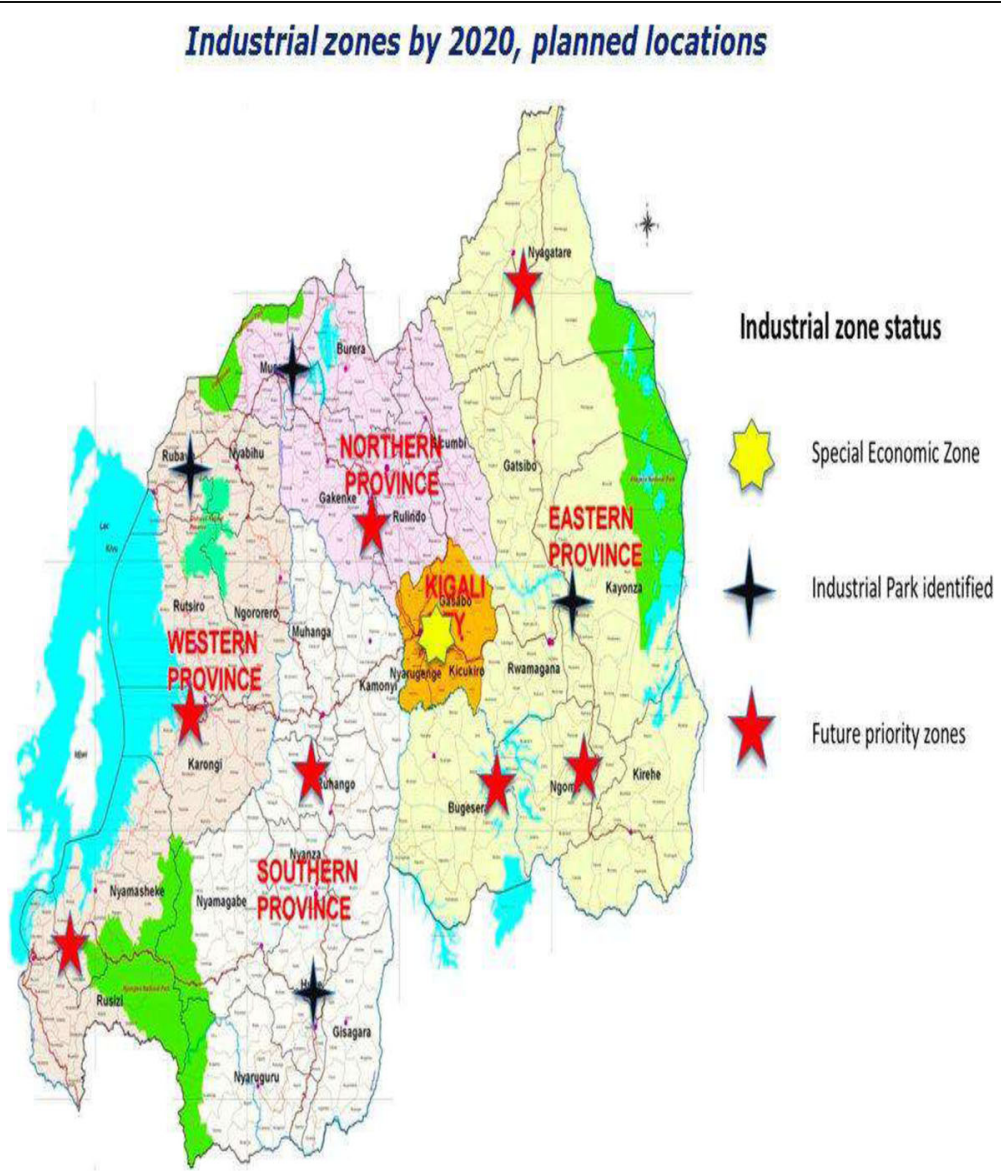

Fig. 3 Industrial Master Plan Site Locations

annual data on industrial production, annually industrial growth, annually water demand, number of employees' and industrial staff strength in water management and other activities. From abattoir users, information obtained was on ownership, available facilities in the abattoir, average number of cows, goats and sheep killed per day, and water management policy.

\section{Estimation methodology for industrial water demand}

The amounts of water needed for industry were calculated by multiplying water demand per unit of industrial production by a measure of industrial production (in units of production). If unit demand were available for each industry, it would be possible to conduct more precise analyses, but in reality only limited data is available. In general, the total water demand of various industries computed using the following empirical relationship as shown in eq. 1(Krinner et al., 1999).

$$
\mathrm{Q}_{\mathrm{i}}=\alpha_{\mathrm{i}} \times \mathrm{X}_{\mathrm{i}}
$$

Where Qi = water demand in any type of industry $\left(\mathrm{m}^{3}\right)$;

$\mathrm{Xi}=$ production by the industry and (unit product); and.

$\alpha \mathbf{i}=$ Specific water demand $\left(\mathrm{m}^{3} /\right.$ unit product $)$. 


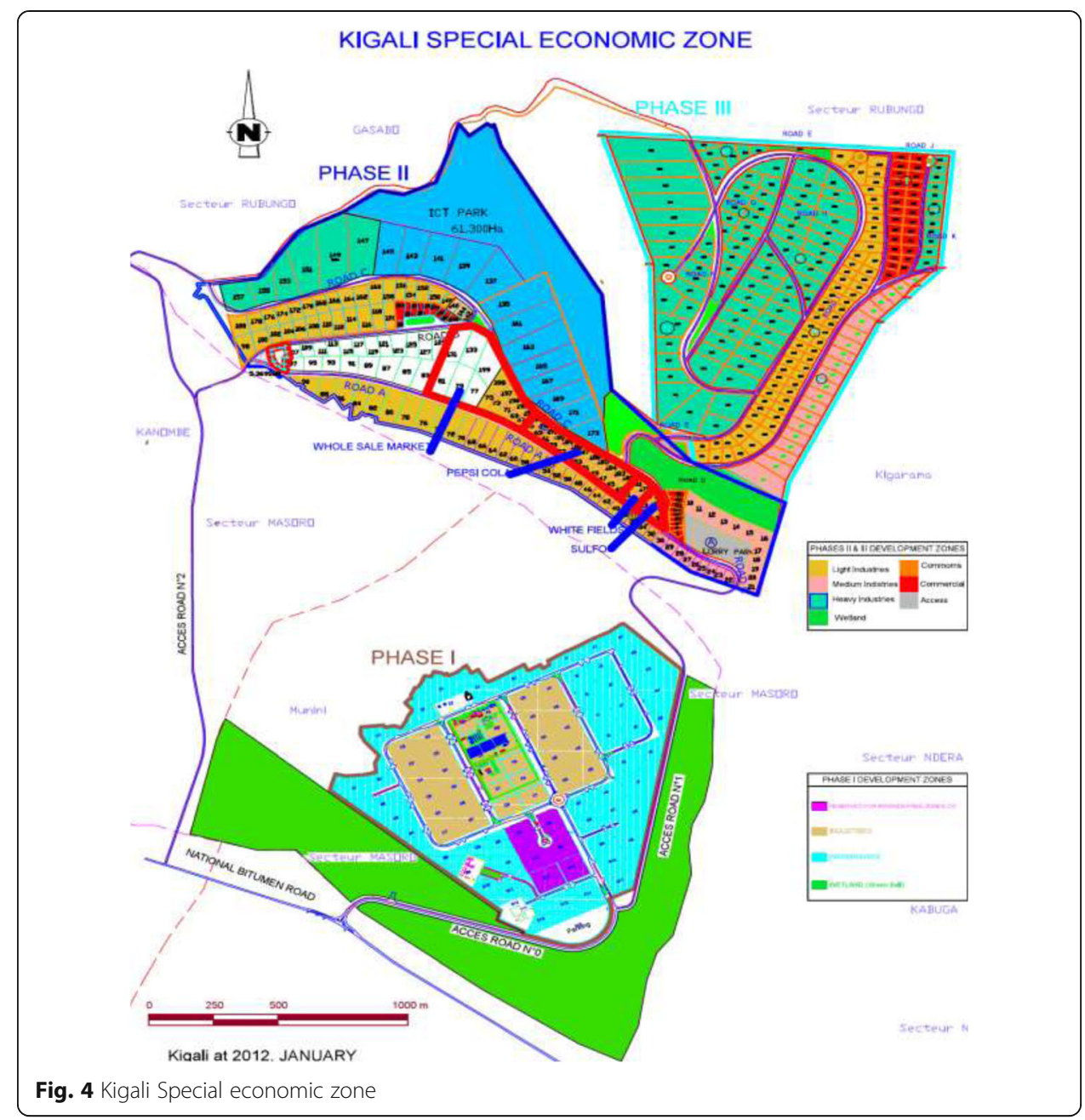

Industrial water demand forecasting methodology

Before constructing water supply facilities, forecasting future water demand is necessary and essential for deciding the size of projects and investments. Water supply facilities have a relatively long-life, and last for as long as 20,30, 50, or even over 100 years. The benefits of long-term water demand forecasting arise from the avoidance of underor over investment.

The approaches to forecasting industrial water demand in this study were to carry out a trend analysis as follows:

- establish the relationship between industrial production and water demand for various sectors;

- assess the trends in industrial production; (Average growth rate obtained from NISR); and

- project trends in industrial production into the future to establish the future water demand.

The linear model used in this research to estimate water demand trends is given in eq. 2: 
Table 3 Industrial water use questionnaire

Indicate business sector in which the company operates from list below

- Fabricated metal products

Battery manufacturers

- Food processing

Plastics products

- Tobacco

Brewery industry:

- Soap - Detergent:

Sugar Production Industry

- Manufacture of textiles

Mining

- Milk, confectionery processing

others

- Soap-detergents/cleaning-polishing-perfumes

- Paper Industry

What are your principal raw materials?

Give details of the main company activities/products:

Source of Water used in Factory: River, ground water, public water

Daily Water Used in Industrial Process

Water Used for Mixing

Water Used for condensation Process

Water used for Cleaning the system

$\mathrm{m}^{3}$

Water used by boiler System

$\mathrm{m}^{3}$

Water used for Cooling System

$\mathrm{m}^{3}$

Water Used for recycling

$\mathrm{m}^{3}$

Number of Employees

$\mathrm{m}^{3}$

Water consumed by Employees

$\mathrm{m}^{3}$

Water used for Floor Washing

Water used for miscellaneous

$\mathrm{m}^{3}$

$\mathrm{m}^{3}$

Total daily Industrial water used

$\mathrm{m}^{3}$

Monthly water used

$\mathrm{m}^{3}$

$\mathrm{m}^{3}$

Annually Industrial water consumption

$\mathrm{m}^{3}$

Annually Water consumption Records

$\mathrm{m}^{3}$

Does your Factory have water Treatment

Facility and water Saving Policy

Industrial Production

Daily Production

(Kg / tones) or (Liters / Cubic meter)

Monthly Production

(Kg / tones) or (Liters / Cubic meter)

Annually Production

(Kg / tones) or (Liters / Cubic meter)

Annually Records For Production

(Kg / tones) or (Liters / Cubic meter)

Table 4 List of people interviewed for data collection

\begin{tabular}{lll}
\hline S/N & Institution/Industries & People \\
\hline 1 & Kabuye sugar Factory & Managing Director and Technicians \\
2 & Meat processing industry & Technicians \\
3 & Tomato paste production industry/ SORWATOM & Director of production \\
4 & Maize flour/ & Production officer and Technician \\
5 & MINIMEX & \\
6 & Breweries Industries & Production officer \\
7 & Water and Sanitation Corporation (WASAC) Ltd & Urban water supply officer \\
\hline
\end{tabular}


Table 5 Types of industries surveyed

\begin{tabular}{llll}
\hline Food industries & & Chemical industries \\
1 & Sugar Manufacturing industry & 1 & Soap manufacturing industries \\
2 & Tomato paste Manufacturing industry & 2 & Cosmetics Manufacturing industries \\
3 & Bakeries production industries & 3 & Paints manufacturing industry \\
4 & Biscuit production industries & 4 & Textile industry \\
5 & Flour production Industries & 5 & Paper printing \\
6 & Meat processing Industries (Abattoir) & 6 & Mattresses Production \\
7 & Coffee processing industry & & \\
Beverage industries & & Metals and Plastic industries \\
1 & Carbonate soft drink & 1 & Roofing Materials (Iron sheets) \\
2 & Beer production industries & 2 & Metallic tubes and profile \\
3 & Banana Industries & 3 & Plastic tubes and water tanks \\
4 & Juice production Industries & & \\
5 & Milk Production Industries & & \\
6 & Butter production & & Hydropower Industries \\
7 & Yoghurt and jam & Mukungwa hydropower Plant \\
8 & Mineral water & & Ntaruka Hydropower plant \\
\hline & Other Industries & & Rukarara Hydropower plant and others \\
\hline & Mining Industry & 3 & \\
\hline
\end{tabular}

$$
\mathrm{Q}_{\mathrm{i}+\mathrm{n}}=\mathrm{Q}_{\mathrm{i}}^{*}\left(1+\mathrm{n}^{*} \frac{\mathrm{a}}{100}\right)
$$

where $Q_{\text {I }}=$ water demand at year $\mathrm{I}\left(\mathrm{m}^{3}\right)$;

$\mathrm{Q}_{\mathrm{i}+\mathrm{n}}=$ Forecasted water demand after $\mathrm{n}$ years $\left(\mathrm{m}^{3}\right)$;

$\mathrm{n}=$ design period (2020 and 2050); and.

$\mathrm{a}=$ average annually growth rate (from NISR) (\%).

\section{Data analysis}

Data analysis involved critical examination of data collected from records, interviews, questionnaires and sites visit.

\section{Water demand and linear models}

Linear model is selected in this research to assess the relationship between water demand and industrial production. In general, water demand relationships are in the form of mathematical equations which express water demand as a mathematical function of independent variables as given in eq. 3 .

$$
y=b+m x
$$

where b intercept;

m slope of linear model; and

$x$ is a set of explanatory variables (see Fig. 5).

However, because of different components of aggregate water demand may be determined by different subsets of explanatory variables, linear model technique in 


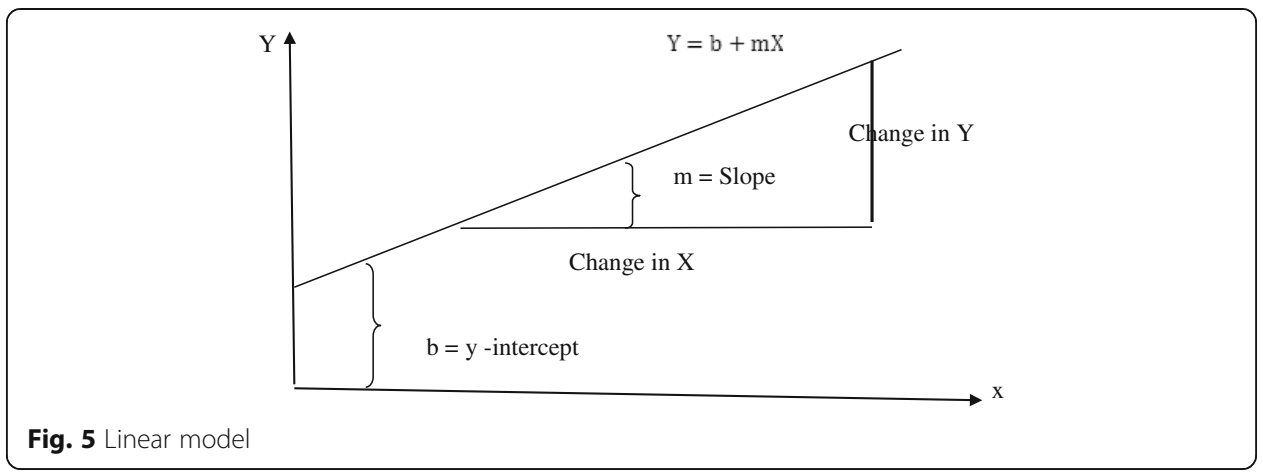

decision making especially in planning where decision makers have to forecast what will happen in the future on the basis of past and current conditions is used in this research.

\section{Correlation coefficient}

Correlation coefficient is a measure of association between two variables, and it ranges between -1 and 1 . If the two variables are in perfect linear relationship, the correlation coefficient will be either 1 or -1 . The sign (+ or - ) depends on whether the variables are positively or negatively, respectively. The correlation coefficient is 0 if there is no linear relationship between the variables.

\section{Coefficient of determination $R^{2}$}

The Coefficient of determination in this research was used to analyze the variability in water demand explained by industrial production. The coefficient of determination is the portion of the total variation in the dependent variable that is explained by variation in the independent variable. The coefficient of determination is also called $R$-squared and is denoted as $R^{2}$. It ranges from $0<R^{2}<1$. If $R^{2}=0$ means that there is no linear relationship between $x$ and $y$; the value of $Y$ does not depend on $\mathrm{x}$. None of the variation in $\mathrm{y}$ is explained by variation in $\mathrm{X}$ (Heron, 2009).

\section{Results and discussions}

\section{Sugar making industry}

Kabuye Sugar works is the unique sugar production industry in Rwanda. The factory has an installed production capacity of 17,000 tons/year. Ever since establishment, the company has never managed to produce enough sugar for the domestic market demand due to the lack of sufficient raw materials. Specific water demand for sugar production at Kabuye sugar works is estimated at $29 \mathrm{~m}^{3} /$ ton. This study showed that specific water demand is higher than the recommended best practice of $25 \mathrm{~m}^{3} /$ ton. Improvements need to be made to achieve the recommended best practice as shown in Table 6 .

Table 6 Specific water demand for Sugar production (André, 2015)

\begin{tabular}{llll}
\hline Rwanda & Brazil & International benchmark & Best practice \\
\hline $29 \mathrm{~m}^{3} /$ ton & $22 \mathrm{~m}^{3} /$ ton & $25-30 \mathrm{~m}^{3} /$ ton & $25 \mathrm{~m}^{3} /$ ton \\
\hline
\end{tabular}




\section{Meat processing industry (Nyabugogo abattoir)}

The products from Nyabugogo abattoir plants are usually dressed carcasses, which are sold on a wholesale basis to butchers and other meat processing plants. Hygiene standards necessitate the demand of large quantities of fresh water. Specific water demand for meat processing in Rwanda for abattoir plant is estimated at $5 \mathrm{~m}^{3}$ /ton. Specific water demand in Rwanda for abattoir plant is low comparing to global benchmark; Europe; and UK as shown in Table 7. The survey of Australian Meat Processor Corporation members showed that larger plants used much more water per unit of production than smaller plants. However larger plants have reduced their water usage from 9.4 to $8.64 \mathrm{~m}^{3}$ per ton hot standard carcass weight since a survey in 2009.

Processing large quantities of potable water can be used during meat processing for washing yards and unloading areas, stock, floors, equipment, product and hands of personnel (Neil \& Jay, 2009). Improvements need to be made in order to achieve the recommended best practice of $2 \mathrm{~m}^{3} /$ ton. The best practice usage relies heavily on installing water-efficient devices on taps and basins to ensure efficient use and re-use of water in cleaning processes and develop a culture of water conservation. Correlation between water demand and meat production as shown in Figs. 6, 7 is analyzed by using a linear regression model. The results are shown in Fig. 8, and eq. 4 .

Correlation coefficient $r$, between water demand and meat production, obtained from the analysis is 0.48 , and the $\mathrm{R}^{2}$ is 0.23 . Thus from this linear model about $23 \%$ of the variation in water demand can be explained by the change in meat production.

$$
\mathrm{Qi}=629.87+2.82 \mathrm{P}
$$

Where Qi is water demand for abattoir in $\mathrm{m}^{3}$;

$\mathrm{P}$ is the meat produced in Tons.

\section{Tomato paste production industry}

SORWATOM is the unique tomato processing factory in Rwanda. The main products are tomato paste. Specific water demand is estimated at $6 \mathrm{~m}^{3} /$ ton of tomato paste produced in Rwanda as shown in Table 8. The relationship of industrial water demand and tomato paste production as shown in Figs. 9, 10 was analyzed by using a linear regression model.

The results are shown in Fig. 11 and eq. 5. Correlation coefficient r, between water demand and tomato paste production, obtained from the analysis is 0.99 , and the $R^{2}$ is 0.98. Thus from this linear model, about $98 \%$ of the variation in water demand can be explained by variation of tomato paste production due to high relationship between water demand and tomato paste production and may be suitable for prediction (see Fig 11).

Table 7 Specific water demand for abattoir meat processing

\begin{tabular}{llllll}
\hline Rwanda & Europe & UK & Australia & Benchmark & Best practice \\
\hline $5 \mathrm{~m}^{3} /$ ton & $5-10 \mathrm{~m}^{3} /$ ton & $5-15 \mathrm{~m}^{3} /$ ton & $9.13 \mathrm{~m}^{3} /$ ton & $2-15 \mathrm{~m}^{3} /$ ton & $2 \mathrm{~m}^{3} /$ ton \\
& $1.6-8.3$ & & & & \\
\hline
\end{tabular}




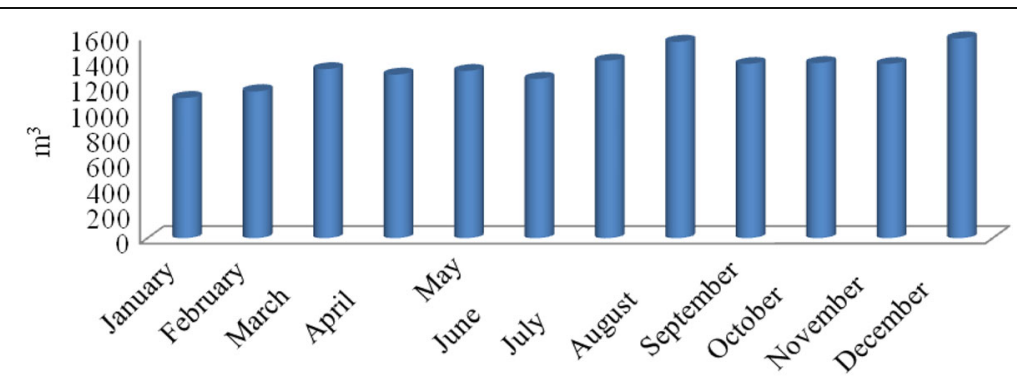

Fig. 6 Annually water demand for abattoir meat production

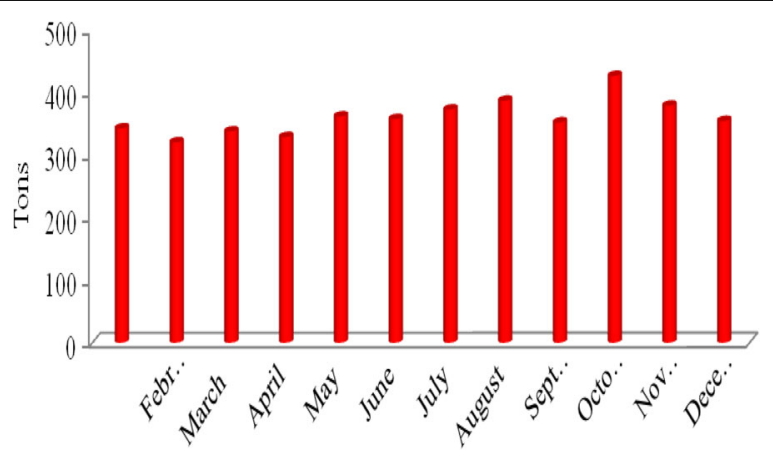

Fig. 7 Annually meat production

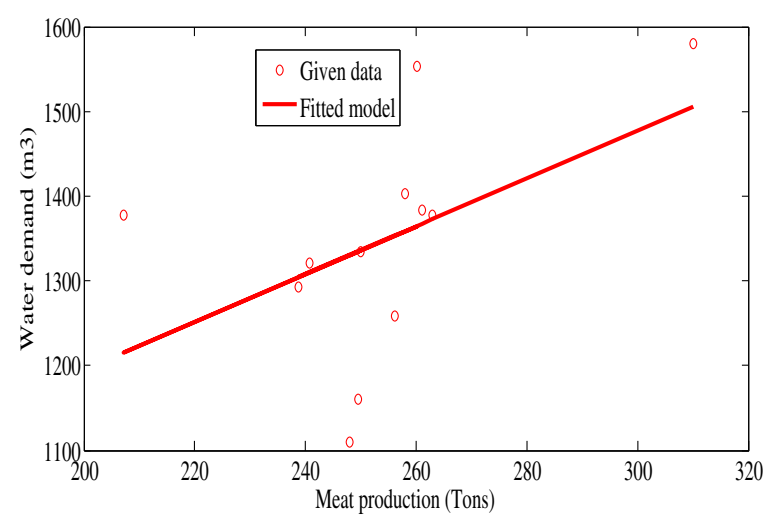

Fig. 8 Linear model between water demand and meat production

Table 8 Specific water demand for tomato paste production (Logan, 1984; Mannapperuma et al., 1993)

\begin{tabular}{ll}
\hline Rwanda & US \\
\hline $6 \mathrm{~m}^{3} /$ ton & $3.58 \mathrm{~m}^{3} /$ ton
\end{tabular}




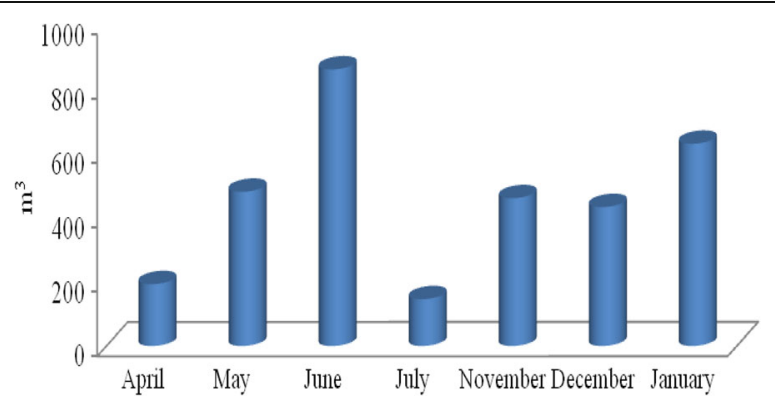

Fig. 9 Water demand for Tomato production Industry

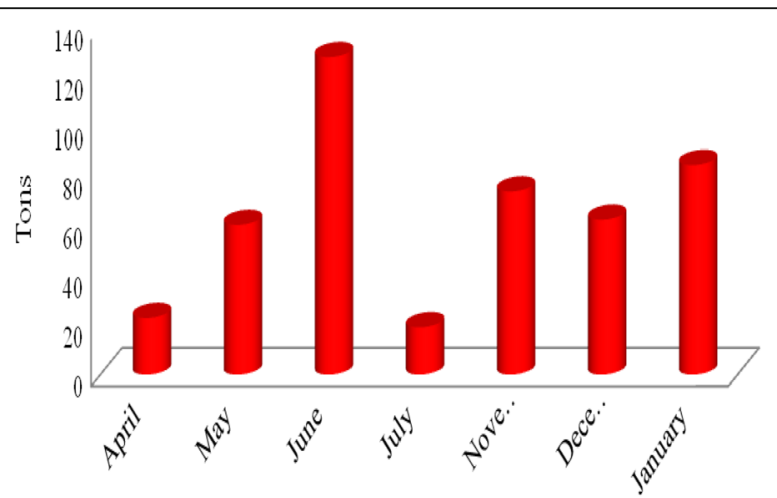

Fig. 10 Tomato paste production

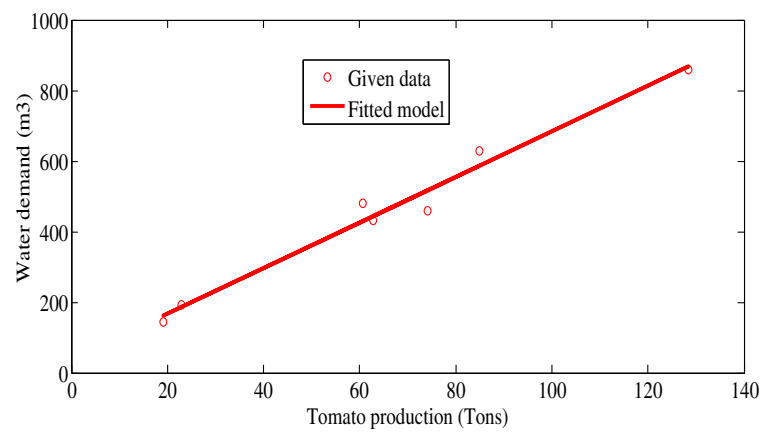

Fig. 11 Linear model between water demand and tomato paste production 


$$
\mathrm{Qi}=37.4+6.48 \mathrm{P}
$$

Where Qi is water demand for tomato paste production in $\mathrm{m}^{3}$; and.

$\mathrm{P}$ is tomato paste production in Tons.

\section{Tobacco manufacturing industry}

Premier Tobacco Company is the unique tobacco processing factory in Rwanda. Dry Tobacco leaf is the primary ingredient. In tobacco production, water is used for steam generation by boiler machine, conditioning; cleaning of machines and domestic purpose. Specific water demand for tobacco production is estimated at $10 \mathrm{~m}^{3} /$ tons. The relationship between industrial water demand and tobacco production as shown in Figs. 12, 13 was analyzed by using a linear regression model.

The results are shown in Fig. 14 and eq. 6. The correlation coefficient r, between water demand and tobacco production, obtained from the analysis is 0.45 , and the $\mathrm{R}^{2}$ is 0.2. Thus from this linear model about $20 \%$ of the variation in water demand can be explained by variation in tobacco production.

$$
\mathrm{Qi}=81.89+6.5 \mathrm{P}
$$

Where: Qi is water demand for tobacco production in $\mathrm{m}^{3}$; $\mathrm{P}$ is Tobacco produced in Tons.

\section{Maize flour}

MINIMEX is the leading company in maize flour production in Rwanda. Specific water demand for maize flour production is estimated at $1.7-2 \mathrm{~m}^{3} /$ tons. Specific water demand in Rwanda is safe compare to global benchmark 2-6 $\mathrm{m}^{3} /$ ton and meets the recommended best practice of $2 \mathrm{~m}^{3} /$ ton as shown in Table 9. The relationship between water demand and maize flour production as shown in Figs. 15, 16 was analyzed by using a linear regression model.

The results are shown in Fig. 17 and eq. 7. The correlation coefficient r, between water demand and maize production, obtained from the analysis is 0.46 , and the $\mathrm{R}^{2}$ is

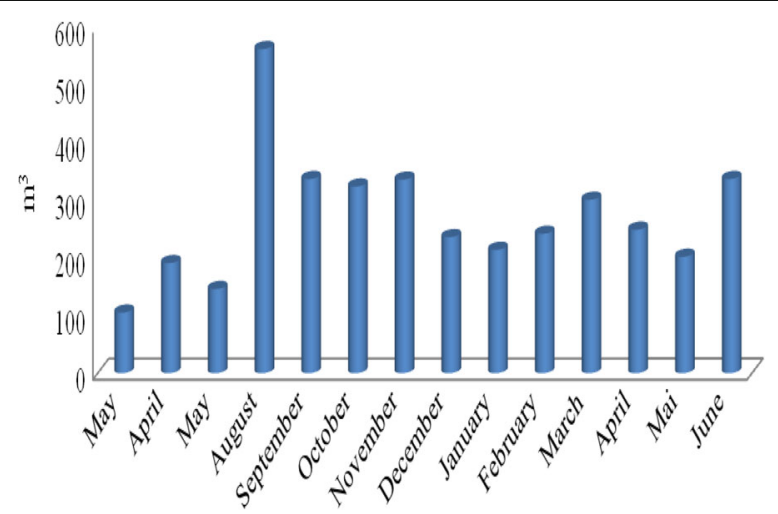

Fig. 12 Annually water demand for Tobacco production 


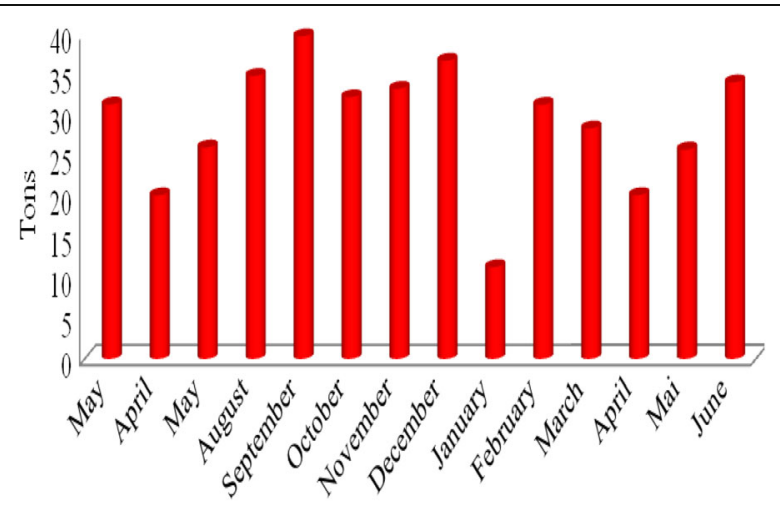

Fig. 13 Annually Tobacco production

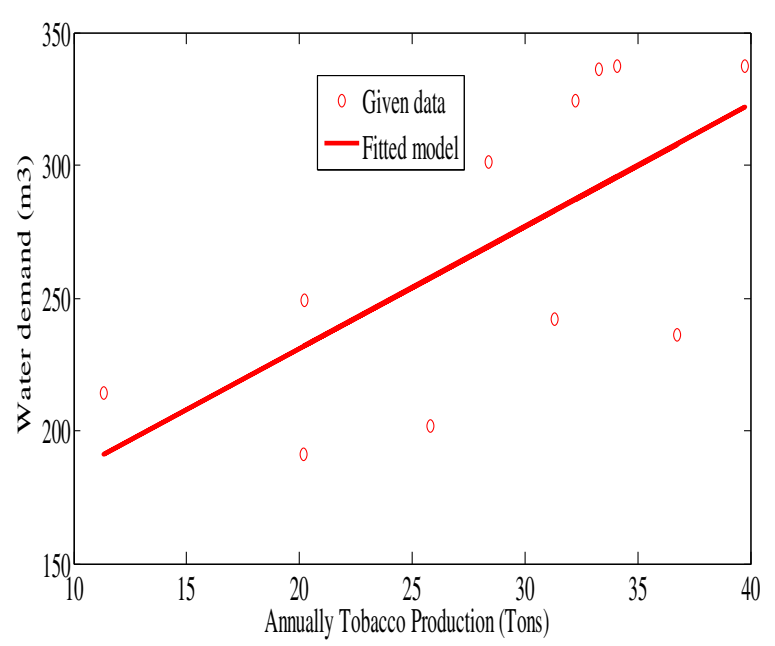

Fig. 14 Linear Model between water demand and tobacco production

Table 9 Specific water demand for Maize flour production

\begin{tabular}{lll}
\hline Rwanda & European Commission & Best practice \\
\hline $1.7-2 \mathrm{~m}^{3} /$ ton & $1.7-3 \mathrm{~m}^{3} /$ ton & $2 \mathrm{~m}^{3} /$ ton
\end{tabular}

Source: Integrated Pollution Prevention and Control, Reference Document on Best Available Techniques in the Food, Drink and Milk Industries August 2006 


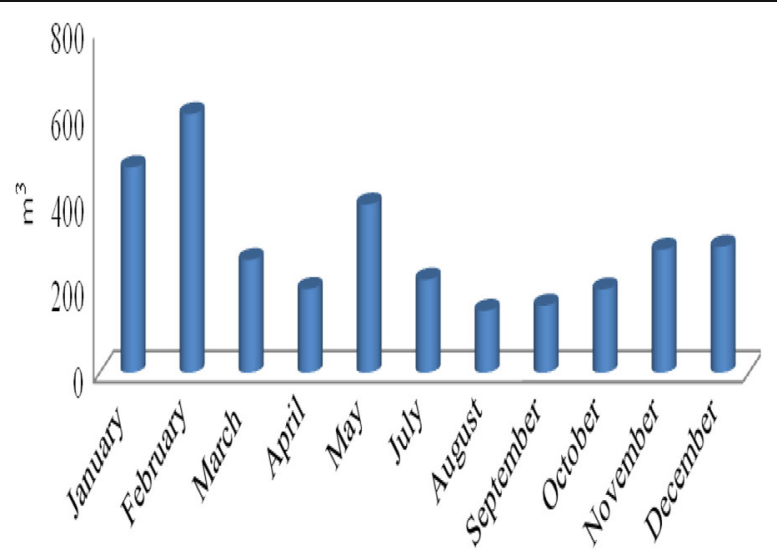

Fig. 15 Annually water demand for maize flour production

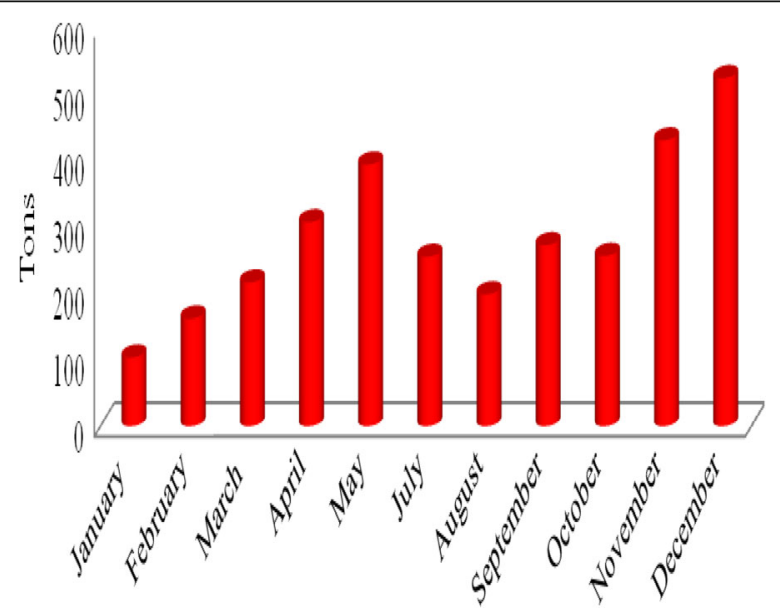

Fig. 16 Annually maize flour production

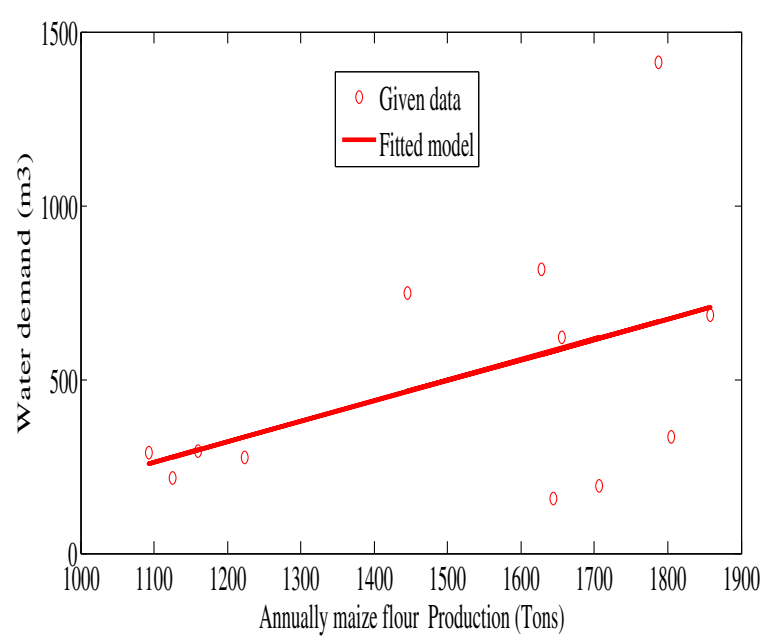

Fig. 17 Linear model between water demand and maize flour production 
Table 10 Specific water demand for beer production (Donoghue \& Jackson, 2012; ABREW, 2007; Oyebode \& Adewumi, 2014)

\begin{tabular}{lllllll}
\hline Rwanda & Ghana & Nigeria & European Brewing Sector & England & Australia & Best practice \\
\hline $4.3-4.6 \mathrm{~m}^{3} / \mathrm{m}^{3}$ & $7.4-9.5 \mathrm{~m}^{3} / \mathrm{m}^{3}$ & $6.5 \mathrm{~m}^{3} / \mathrm{m}^{3}$ & $4.4 \mathrm{~m}^{3} / \mathrm{m}^{3}$ & $4-11 \mathrm{~m}^{3} / \mathrm{m}^{3}$ & $4-10 \mathrm{~m}^{3} / \mathrm{m}^{3}$ & $4.2 \mathrm{~m}^{3} / \mathrm{m}^{3}$ \\
\hline
\end{tabular}

0.21 . Thus from this linear model about $21 \%$ of the variation in water demand can be explained by variation in maize flour production.

$$
\mathrm{Qi}=1331.7+0.3561 \mathrm{P}
$$

Where: Qi is water demand for maize flour production in $\mathrm{m}^{3}$; $\mathrm{P}$ is maize flour produced in Tons.

\section{Beer production industry}

The brewing industry is one of the largest industrial water demands in Rwanda. Average specific water demand in the assessed beer production industry in Rwanda ranges from 4.3 to $4.5 \mathrm{~m}^{3}$ of water per $\mathrm{m}^{3}$ of beer produced. Specific water demand for beer production industry in Rwanda is low compare global benchmark of $6.5 \mathrm{~m}^{3} / \mathrm{m}^{3}$ and England as shown in Table 10. Improvements need to be made in order to achieve the recommended best practice of four $\mathrm{m}^{3}$ of raw water for every $\mathrm{m}^{3}$ of beer produced. (UNEP, 2012).

The best practice can be achieved develop efficient cleaning practices which minimize use of water. Devices to manage flow in cleaning can also be used. Implement water saving devices for employee use (low water toilets, lower flow taps, etc). The relationship between water demand and beer production as shown in Figs. 18, 19 was analyzed by using a linear regression model.

The results are shown in Fig. 20 and the eq. 8. Correlation coefficient r, between water demand and beer production, obtained from the analysis is 0.28 , and the $R^{2}$ is 0.08 . Thus from this linear model about $8 \%$ of the variation in water demand can be explained by variation in beer production.

$$
\mathrm{Qi}=26252+1.69 \mathrm{P}
$$

Where Qi is water demand for beer production in $\mathrm{m}^{3}$; and.

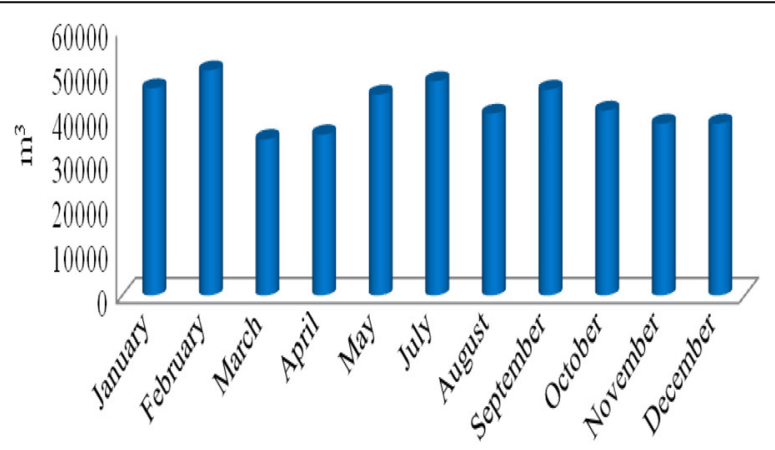

Fig. 18 Annually water demand for beer production 


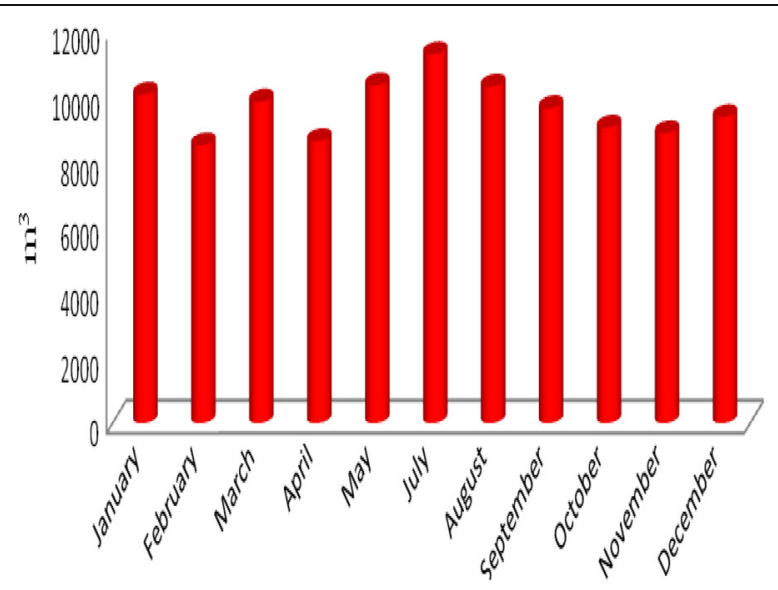

Fig. 19 Annually beer production

$\mathrm{P}$ is beer produced in $\mathrm{m}^{3}$.

\section{Carbonate soft drink manufacturing}

Water is the most important ingredient in all beverage products. Specific water demand for a carbonate soft drink production in Rwanda was estimated at $4 \mathrm{~m}^{3} / \mathrm{m}^{3}$. Specific water demand for carbonated soft drink production in Rwanda is safe compare to international benchmark and England as shown in Table 11. Improvements need to be made in order to achieve the recommended best practice of 3 $\mathrm{m}^{3} / \mathrm{m}^{3}$ of carbonate soft drink production. The relationship between water demand and carbonate soft drink production as shown in Figs. 21 and 22 was analyzed by using a linear regression model. The results are shown in Fig. 23 and eq. 9. Correlation coefficient $r$, between water demand and carbonate soft drink production,

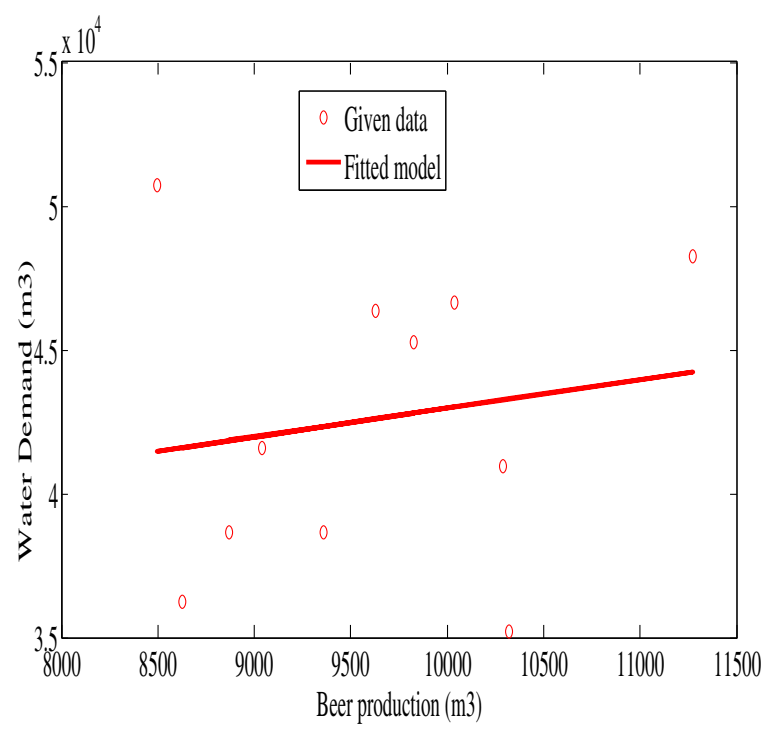

Fig. 20 Linear model between water demand and beer production 
Table 11 Specific water demand for carbonate soft drink (Foster et al., 2006; UNIDO, 2014; Rees et al., 2003)

\begin{tabular}{llll}
\hline Rwanda & England & Global benchmark & Best practice \\
\hline $3.8 \mathrm{~m}^{3} / \mathrm{m}^{3}$ & $4-4.25 \mathrm{~m}^{3} / \mathrm{m}^{3}$ & $6.5 \mathrm{~m}^{3} / \mathrm{m}^{3}$ & $3 \mathrm{~m}^{3} / \mathrm{m}^{3}$ \\
\hline
\end{tabular}

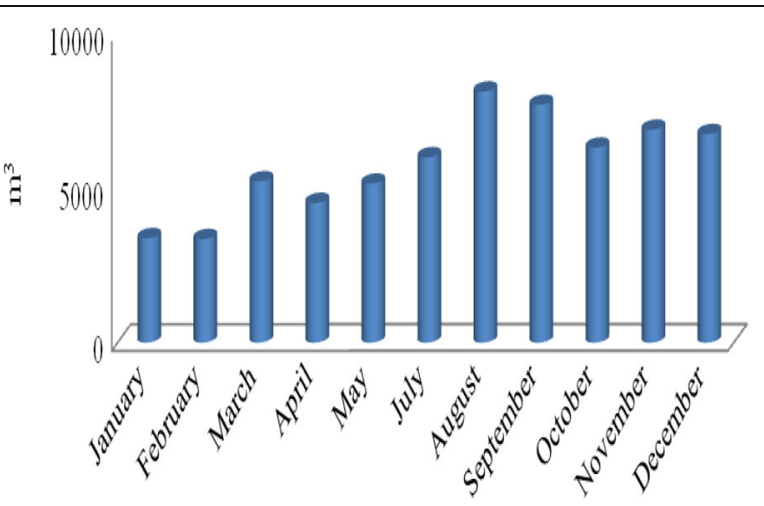

Fig. 21 Annually water demand for the production of soft drink

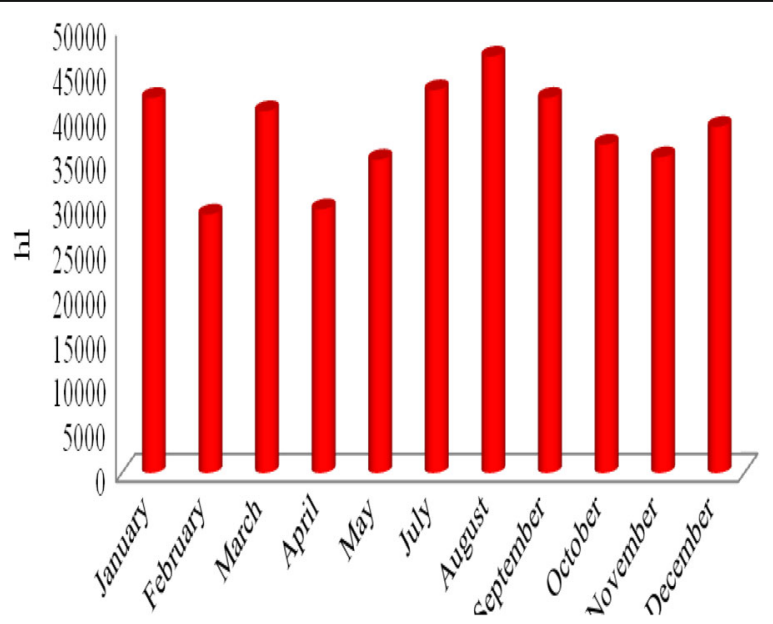

Fig. 22 Annually carbonate soft drink production 


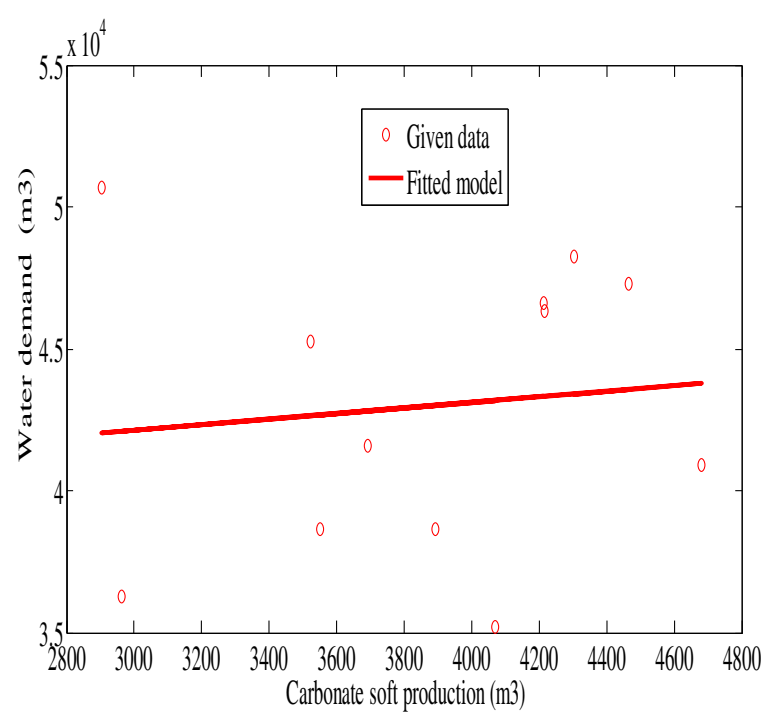

Fig. 23 Linear model for carbonate soft drink and water demand

obtained from the analysis is 0.11 , and the $\mathrm{r}^{2}$ is 0.012 . Thus from this linear model about $1.2 \%$ of the variation in water demand can be explained by variation of carbonate soft drink production.

$$
\mathrm{QI}=39170+0.98 \mathrm{P}
$$

Where Qi is water demand for carbonate soft drink production in $\mathrm{m}^{3}$; and.

$\mathrm{p}$ is carbonate soft drinks produced in $\mathrm{m}^{3}$.

A correlation coefficient of +1.00 tells you that there is a perfect positive relationship between the two variables. This means that as values on one variable increase there is a perfectly predictable increase in values on the other variable. In other words, as one variable goes up so does the other. In this research Tomato Paste production industry shown strong relationship because as, as water demand is increasing also production is increasing, thus from this linear model, about $98 \%$ of the variation in water demand can be explained by variation of tomato paste production due to high relationship between water demand and tomato paste production and may be suitable for prediction, other industries shown fair, weak and very weak correlation as shown in Table 12 due to different factors such as water used in hygiene, cleaning equipments, domestic purposes

Table 12 Summary table for correlation analysis

\begin{tabular}{lllll}
\hline S/N & Industries names & $r$ & $R^{2}$ & Results interpretation \\
\hline 1 & Abattoir Industries & 0.48 & 0.23 & Fair or moderate correlation \\
2 & Tomato paste production industry (Sorwatom) & 0.99 & 0.98 & Very strong/high correlation \\
3 & Tobacco manufacturing industry & 0.45 & 0.2 & Fair/Moderate \\
4 & Maize flour & 0.46 & 0.21 & Fair/Moderate \\
5 & Beer production industry & 0.28 & 0.08 & Poor/weak correlation \\
6 & Carbonate soft drink manufacturing & 0.11 & 0.012 & Very Poor/Very weak correlation \\
\hline
\end{tabular}

Where $\mathrm{r}$ : correlation coefficient and $\mathrm{R}^{2}$ coefficient of determination 
and steam production. The relationship between climate change, urbanization and to industrial water demand was not considered in this study because of availability of data.

\title{
Concluding remarks
}

The present study shows that the brewery industries in Rwanda have shown best practice of water demand for production of carbonate soft drinks and beer with specific water demand of 4 to $4.5 \mathrm{~m}^{3} / \mathrm{m}^{3}$ of final product in which is less than the global bench mark of $6.5 \mathrm{~m}^{3} / \mathrm{m}^{3}$. Improvements need to be made in order to achieve the recommended best practice of three cubic meters of raw water for every cubic meter of carbonate soft drinks and four cubic meters of raw water for every cubic meter of beer produced. A correlation coefficient of +1.00 tells you that there is a perfect positive relationship between the two variables. This means that as values on one variable increase there is a perfectly predictable increase in values on the other variable. In other words, as one variable goes up so does the other. In this research Tomato Paste production industry shown strong relationship because as, as water demand is increasing also production is increasing Thus from this linear model, about $98 \%$ of the variation in water demand can be explained by variation of tomato paste production due to high relationship between water demand and tomato paste production and may be suitable for prediction, other industries shown fair, weak and very weak correlation due to different factors such as water used in hygiene, cleaning equipments, domestic purposes and steam production. The relationship between climate change, urbanization and to industrial water demand was not considered in this study because of availability of data. It is recommended that the relationship between climate change, urbanization and to industrial water demand to be investigated in further research.

\begin{abstract}
Abbreviations
EU: European Union; FAO: Food and Agriculture Organization of the United Nations; ICT: Information and Communication Technology; MINICOM: Ministry of Trade and Industry; NISR: National Institute of Statistics of Rwanda; PSCBS: Public Sector Capacity Building Secretariat; RDC: Republic Democratic of Congo; REB: Rwanda Education Board; SORWATOM: Societe Rwandaise de Traitement de Tomates; UNEP: United Nations Environment Programme; UNIDO: United Nations Industrial Development Organization; UR: University of Rwanda; WASAC: Water and Sanitation Corporation
\end{abstract}

\section{Acknowledgements}

The work reported here was undertaken the staff of the University of Rwanda (UR), College of Science and Technology. The authors wish to acknowledge the support of Government of Rwanda, through Public Sector Capacity Building Secretariat (PSCBS). We also express sincere gratitude to governmental agencies such as Rwanda Water and Sanitation Corporation (WASAC) and National Institute of Statistics of Rwanda that provided all data used in this study.

\section{Funding}

This research was funded by the Government of Rwanda through Public Sector Capacity Building Secretariat (PSCBS).

\section{Author declaration}

We the undersigned declare that this manuscript is original, has not been published before and is not currently being considered for publication elsewhere. We confirm that the manuscript has been read and approved by all named authors and that there are no other persons who satisfied the criteria for authorship but are not listed. We further confirm that the order of authors listed in the manuscript has been approved by all of us.

\section{Authors' contributions}

Acquisition of data \& data collection, analysis and interpretation: Eng. EM. Study conception, data analysis and results interpretation: Dr. Eng. OM. Critical revision and design: Prof. Dr. Eng. UGW. All authors read and approved the final manuscript.

\section{Authors' information}

Eng. Egide Munderere is an Assistant Lecturer at University of Rwanda in the college of Science and Technology, School of Engineering. Eng. Egide completed a BS in Civil Engineering and Environmental Technology at Kigali Institute of Science and Technology in 2010, MS in Water and Environmental Management at the National University of Rwanda in 2013. Phone number: +250,788,591,799. E-mail: egide@yahoo.fr. 
Dr. Eng. Omar Munyaneza is Senior Lecturer at University of Rwanda in the college of Science and Technology, School of Engineering. Dr. Omar completed a BS in Civil Engineering at The National University of Rwanda in 2004, MS in Water and Environmental Management at the National University of Rwanda in 2007. PhD in Hydrology and Water Resources at UNESCO-IHE, Delft, Netherlands in 2012. His Thesis title was: Space-time patterns of hydrological processes and water resources in Rwanda, with special focus on the meso-scale Migina catchment. Dr. Omar published 17 papers in peer-reviewed journals and 22 papers in conference proceedings. He published 2 books and supervised 88 undergraduates students and $17 \mathrm{MSc}$ students with co-supervision of $2 \mathrm{PhD}$ students. Dr. Omar is now Coordinator of Research and Innovation at University of Rwanda, School of Engineering. E-mail Phone number: +250,788,560,783; omarmiunyaneza1@gmail.com.

Prof. Dr. Eng. Umaru Garba Wali is a Professor of Hydraulics and Hydrology Engineering at University of Rwanda in the college of Science and Technology, School of Engineering. And Coordinator of Master's Program in Water Resources and Environmental Management at University of Rwanda. Prof. Wali completed a BS in OND in Agricultural Mechanization, Collage of Agriculture and Animal Husbandry, Zuru in 1987, MS in Technical Sciences (Irrigation, Drainage, Land Development and Water Supply), Byelorussian Agricultural Academy, Gorki Belarus in 1995. PhD in Technical Sciences (Hydraulics and Engineering hydrology), Moscow State University of Environmental Engineering, Moscow, Russia in 2002. Prof. Wali published more than 40 papers in peer-reviewed journals and he published 3 books and supervised many undergraduates students as well as MSc students with 3 PhD students. Phone number: $+250,788,877,174$. E-mail: ugwas@yahoo.com.

Umaru Garba Wali is a Professor of Water and Environmental Engineering at the School of Engineering, College of Science and Technology, University of Rwanda. He is the Dean of the School of Engineering and Coordinator of MSc in Water Resources and Environmental Management. He completed PhD in Technical Sciences (Hydraulics and Engineering Hydrology) from the Moscow State University of Environmental Engineering in 2002. He attended Byelorussian Agricultural Academy, Gorki, Belarus and graduated with MSc in Technical Sciences (Irrigation, drainage, land development and Water Supply) in 1995. He also holds OND in Agricultural Mechanization from the College of Agriculture and Animal Husbandry, Zuru in 1987. He participated in several research and developmental projects. Phone number: +250788877174. E-mail: ugarbawali@gmail.com.

\section{Competing interests}

I declare that I have no significant competing financial; it is academic research and professional interests that might have influenced the presentation of the work described in this manuscript.

\section{Publisher's Note}

Springer Nature remains neutral with regard to jurisdictional claims in published maps and institutional affiliations.

Received: 28 February 2017 Accepted: 4 October 2017

Published online: 25 November 2017

\section{References}

African Brewery Sector Water Saving Initiative (2007) Analysis of water consumption in African breweries with focus on the situation in Ethiopia, Ghana, Morocco and Uganda. UNEP, Division of Technology, Industry \& Economics, Paris

André EN (2015) Management of water resources in the sugarcane agro-industry in Brazil. Academy of Agriculture and Science (KSLA) Stockholm, Sweden

Bob P, Penny P (2004) Eco-efficiency, Water Conservation and Food Processing in Australia. UNEP Working Group for Cleaner Production

COWI (2008) Cleaner production assessment in meat processing. UNEP, DenmarkUnited Nations Environment Program. Division of Technology Industry and Economics. Danish Environmental Protection Agency

Donoghue C, Jackson G (2012) The environmental performance of the European brewing sector. European Union FAO AQUASTAT (2005) L'irrigation en Afrique en chiffres: Enquête AQUASTAT 2005

Foster C, Green K, Bleda M, Dewik P, Evan B, Flynn A, Mylan J (2006) Environmental impact of food production and consumption. Manchester, London

Heron E (2009) Correlation and regression. https://medicine.tcd.ie/neuropsychiatric-genetics/assets/pdf/2009_4_ Regression.pdf

Integrated Pollution Prevention and Control (2006) Reference document on best available techniques in the food, drink and milk industries

Krinner W, Lallana C, Estrela T (1999) Sustainable water use in Europe. EEA, Copenhagen

Logan HS (1984) An annual planning model for food processing. Giannini foundation of agricultural economics. University of California, California

Mannapperuma R, Jatal D, Paul S (1993) Survey of water use in the California food processing industry. University of California, Davis

Neil M, Jay S (2009) A survey of water use and reuse in the Australian Red meat processing industry

Oyebode OJ, Adewumi IK (2014) Life cycle assessment and Management of Water use in selected breweries in Nigeria. Civil Engineering and Architecture 2(5):191-201. 10.13189/cea.2014.020501.

Rees B, Cessford F, Connelly R, Cowan J, Bowell R (2003) Optimum use of water for industry and agriculture. Environment Agency, Bristol

UNEP (2012) Beverage industry environmental roundtable. Water use benchmarking in the beverage.

UNIDO (2014) Greening Food and Beverage Value Chains: the Case of the Soft Drinks Industry, Vienna, Austria.

World Bank (2007) Environmental, health and safety guidelines for meat processing. International France Corporation, Paris 